\title{
Implementasi Pendidikan Karakter dalam Pembelajaran Bahasa Indonesia di SMP Al-Irsyad Surakarta
}

\author{
Feri Revita ${ }^{1)}$, Metha Dewa ${ }^{2)}$, Listy Anjani ${ }^{3)}$, Muhad Fatoni4) \\ 1,2,3,4)Universitas Muhammadiyah Surakarta \\ Ferirevita01@gmail.com \\ doi: 10.23917/blbs.v2i1.11610
}

\begin{abstract}
Abstrak. Tujuan Penelitian ini adalah mengetahui proses implementasi pendidikan karakter dalam membentuk sikap dan perilaku sosial peserta didik melalui pembelajaran bahasa indonesia di SMP AL-IRSYAD Surakarta, mengetahui sikap dan perilaku sosial peserta didik saat pembelajaran sejarah di SMP AL-IRSYAD Surakarta, dan mengetahui kendala apa saja yang di alami guru bahasa Indonesia dalam implementasi pendidikan karakter dalam membentuk sikap dan perilaku sosial peserta didik di SMP AL-IRSYAD Surakarta. Penelitian ini adalah penelitian kualitatif fe- nomenologis. Sasaran penelitian ini adalah guru bahasa indonesia dan siswa kelas VII di SMP AL-IRSYAD Surakarta. Teknik pengumpulan data menggunakan teknik Observasi, dokumentasi dan wawancara. Uji validitas data dengan triangulasi sumber. Teknik analisis data menggunakan reduksi data, display, penarikan kesimpulan dan verifikasi. Hasil penelitian ini adalah proses implementasi pendidikan karakter dalam membentuk sikap dan perilaku sosial siswa di lakukan di luar kelas berkaitan dengan peraturan sekolah yang menjadi kebiasaan dan di dalam kelas di sesuaikan dengan materi yang berhubungan dengan nilai-nilai karakter yang nantinya dapat membentuk sikap dan perilaku sosial siswa. Sikap dan perilaku sosial siswa SMP AL-IRSYAD Surakarta dapat dikatakan sudah baik. Kendala yang di alami guru bahasa indonesia adalah peraturan pemerintah yang berubah-ubah serta karakteristik siswa yang berbeda-beda.
\end{abstract}

Kata Kunci: Pendidikan Karakteristik, Pembelajaran Bahasa Indonesia, Perilaku Sosial dan Sikap Sosial

\section{PENDAHULUAN}

Berdasarkan Undang-Undang Republik Indonesia Nomor 20 tahun 2003 tentang Sistem Pendidikan Nasional menerangkan bahwa pengertian dan proses "pendidikan adalah usaha sadar dan terencana untuk mewu jud ka $\mathrm{n}$ s uasana belajar pembelajaran agar peserta didik secara aktif mengembangkan potensi dirinya untuk memiliki kekuatan spiritual keagamaan, pengendalian diri, kepribadian, kecerdasan, akhlak mulia, serta keterampilan yang diperlukan dirinya, masyarakat, bangsa dan negara". Pendidikan Islam pada awalnya diarahkan pada pembentukan karakter siswa untuk menjadi khalifah yang memiliki fitrah, roh dan jasmani, kemauan yang bebas, dan akal yang sehat agar mereka dapat membangun potensi diri yang berakhlak mulia, sehat, berilmu, cakap, kreatif, mandiri, dan menjadi warga negara yang demokratis serta bertanggung jawab.

Pendidikan merupakan pilar tegaknya suatu bangsa. Melalui pendidikanlah bangsa akan tegak mampu menjaga martabat. 
Dalam era ini, pendidikan bukan hanya terpaku dalam faktor intelektual yang dimiliki sesorang saat menempuh pendidikan namun juga harus diintegrasikan dengan faktor lain seperti halnya sikap, perilaku, dan karakter. Masalah pendidikan di Indonesia sangatlah kompleks karena di semua aspeknya terdapat persoalan yang perlu diselesaikan. Dekadensi moral telah merajalela dalam dunia pendidikan sehingga menjadi potret buram dalam dunia pendidikan. Hal ini bisa dilihat dari maraknya perkelahian antar pelajar, banyaknya kasus narkoba yang menjerat siswa, Siswa yang menunjukkan sikap kurang hormat kepada orang dewasa, kasus menyontek yang sudah menjadi kebiasaan. Persoalan budaya dan karakter bangsa saat ini menjadi sorotan tajam masyarakat. Sorotan itu mengenai berbagai aspek kehidupan, tertuang dalam berbagai tulisan di media cetak, wawancara, dialog, dan gelar wicara di media elektronik (Utomo, 2017: 23). Fenomena ini menjadikan dunia pendidikan berbenah sehingga pendidikan karakter sangat penting saat ini dimana nantinya pendidikan karakter bisa merubah masyarakat menjadi lebih baik lagi.

Alex Agboola dalam jurnal yang berjudul Bring Character Education into Classroom (2012:168) menyatakan bahwa kebijakan pendidikan harus mengambil inisiatif untuk mengaktualisasikan pen didikan moral dalam sistem sekolah. Dilakukan bersamasama, orang tua, guru, dan administrator sebagai pemangku kepentingan, harus bersama-sama bergabung untuk mendorong para siswa mewujudkan nilai-nilai baik dalam hidup mereka, untuk itulah perlu implementasi pendidikan karakter di sekolah atau madrasah sehingga pembentukan karakter tidak hanya dipupuk dari keluarga tetapi juga di bina di sekolah. Karena sekolah merupakan rumah kedua peserta didik dalam hal pembiasaan. Pentingnya pendidikan karakter tidak lepas dari munculnya beberapa fenomena sosial saat ini, yang ditunjukkan dengan perilaku yang tidak berkarakter serta adanya gejala-gejala yang menandakan tergerusnya karakter sebuah bangsa. Perilaku negatif yang muncul dari berbagai kalangan mulai dari masyarakat, pelajar, dan kalangan lainnya menunjukkan bahwa karakter yang dimiliki masih sangat kurang bahkan lebih cenderung saat ini tidak mempunyai karakter yang sesuai dalam norma masyarakat.

Jadi mempelajari karakter tidak lepas mempelajari nilai atau sikap, norma, dan moral. Salah satu unsur dalam karakter seseorang adalah sikap dan perilaku. Sikap sesorang diwujudkan dalam perilaku orang tersebut dan perilaku akan dilihat orang lain dan itu akan membuat orang lain menilai bagaimanakah karakter orang tersebut. Bahkan dari sikap dan perilaku tersebut orang lain 
cenderung menilai sebagai cerminan karakter seseorang tersebut, walaupun hal yang dilihat orang lain tidak tentu benar.

Karakter merupakan kepribadian seseorang yang terbentuk dari hasil interna- lisasi berbagai nilai-nilai yang diyakini dan digunakan sebagai landasan untuk berpikir dan bertindak. Hasan (2010:3) mengatakan bahwa karakter adalah watak, tabiat, akhlak, atau kepribadian seseorang yang terbentuk dari hasil internalisasi berbagai kebajikan yang diyakini dan digunakan sebagai landasan untuk cara pandang, berpikir, bersikap, dan bertindak. Definisi karakter tersebut dapat dipahami bahwa karakter merupakan manifestasi dari sifat-sifat yang dise-but kebajikan.

Menurut Megawangi (Kesuma, 2011), pendidikan karakter adalah sebuah usaha sadar untuk mendidik anak-anak agar dapat mengambil keputusan dengan bijak dan mempraktikkannya dalam kehidupan sehari-hari sehingga mereka dapat memberikan kontribusi yang positif kepada lingkungan.

a. Lickona (Sudrajat, 2011:49) menyatakan bahwa terdapat tujuh hal yang melatarbelakangi pentingnya pendidikan karakter seperti berikut.

b. Cara terbaik untuk menjamin anak-anak (siswa) memiliki kepribadian yang baik dalam kehidupannya.

c. Cara untuk meningkatkan prestasi akademik.

d. Sebagian siswa tidak dapat membentuk karakter yang kuat bagi dirinya di tempat lain.

e. Persiapan siswa untuk menghormati pihak atau orang lain dan dapat hidup dalam masyarakat yang beragam.

f. Berangkat dari akar masalah yang berkaitan dengan problem moral sosial, seperti ketidaksopanan, ketidakjujuran, kekerasan, pelanggaran kegiatan seksual, dan etos kerja (belajar) yang rendah.

g. Persiapan terbaik untuk menyongsong perilaku di tempat kerja.

h. Pembelajaran nilai-nilai budaya yang merupakan bagian dari kerja peradaban.

Deal dan Kent (Moerdiyanto, 2012:3) mendefinisikan kultur sekolah sebagai ke- yakinan dan nilai-nilai milik bersama yang menjadi pengikat kuat kebersamaan sebagai warga sekolah. Setiap sekolah memiliki keunikan berdasarkan pola interaksi komponen warga sekolah secara internal dan eksternal. Menurut Efianingrum (2008:5), setiap sekolah mempunyai kebudayaannya sendiri yang bersifat unik, memiliki aturan tata tertib, kebiasaan-kebiasaan, upacara-upacara, mars/hymne sekolah, pakaian seragam, dan lambang-lambang yang lain yang memberikan corak khas kepada sekolah yang bersangkutan. Oleh karena itu, dengan memahami 
ciri-ciri kultur sekolah akan dapat dilakukan tindakan nyata dalam perbaikan kualitas kultur sekolah.

Artikel ini bertujuan untuk mengetahui sejauh mana pengaruh implementasi pendidikan karakter ketika pembelajaran mata pelajaran Bahasa Indonesia berlangsung, khususnya di kalangan SMP AL-IRSYAD Surakarta. Serta untuk memberi pemahaman dan kesadaran mengenai pentingnya bahasa Indonesia dalam proses pembelajaran. Selain itu, penulisan artikel ini juga mengharapkan agar siswa mampu dan berminat mempelajari bahasa Indonesia sebagai bekal untuk kehidupan dikemudian hari.

\section{METODE PENELITIAN}

Penelitian ini merupakan penelitian deskriptif dengan menggunakan pendekatan kualitatif. Penelitian ini bertujuan untuk mendeskripsikan implementasi pendidikan karakter dalam pembelajaran Bahasa Indonesia dan bertujuan untuk memahami lebih mendalam bagaimana Implementasi pendidikan karakter dalam pembelajaran diimplementasikan pada sekolah. Penelitian ini dilakukan di SMP AL-ISRYAD Surakarta. Teknik pengumpulan data yang digunakan dalam penelitian ini adalah wawancara, observasi, dan dokumentasi. Wawancara merupakan percakapan dengan maksud tertentu. Percakapan itu dilakukan oleh dua pihak, yaitu pewawancara (interviewer) yang mengajukan pertanyaan dan yang diwawancarai yang memberikan jawaban atas pertanyaan itu (Moleong, 2007:135). Wawancara digunakan untuk menjaring data atau informasi yang berkaitan dengan berbagai kebijakan yang dilakukan sekolah dalam implementasi pendidikan karakter. Observasi dilakukan untuk melihat implementasi pendidikan karakter melalui kultur di sekolah. Dokumentasi digunakan untuk memperoleh data tentang kegiatan rutin sekolah dan rencana pembelajaran yang dibuat oleh guru. Untuk memperoleh data yang dapat dipertanggungjawabkan secara ilmiah, dalam penelitian ini dilakukan pemeriksaan keabsahan data. Dalam penelitian ini teknik pemeriksaan keabsahan data yang digunakan adalah teknik triangulasi.

\section{HASIL PENELITIAN DAN PEMBAHASAN}

Secara geografis letak SMP AL-IRSYAD Surakarta sangat strategis, karena mudah dijangkau kendaraan umum atau angkutan kota yang menuju ke arah kota Surakarta. Terletak $2 \mathrm{~km}$ dari Pasar Gede, yang merupakan salah satu pusat perdagangan di Kabupaten surakarta. Keberadaan SMP AL-IRSYAD Surakarta memberikan kontribusi cukup besar bagi suksesnya program pendidikan. Di SMP AL-IRSYAD Surakarta juga terdapat banyak 
sekali ekstrakuriku ler yang diharapkan akan membantu siswa untuk lebih mengembangkan bakatnya di bidang non akademik. Beberapa ekstrakurikuler tersebut adalah: : Pramuka, tata boga, memanah, futsal, basket, taekwondo, pencak silat, dll.

Dalam pelaksanaan pendidikan karakter tidak lepas dari fungsi dan tujuan pendidikan nasional yaitu, Pendidikan nasional berfungsi mengembangkan kemampuan dan membentuk watak serta peradaban bangsa yang bermartabat dalam rangka mencerdaskan kehidupan bangsa, bertujuan untuk berkembangnya potensi peserta didik agar menjadi manusia beriman dan bertakwa kepada Tuhan Yang Maha Esa, berakhlak mulia, sehat, berilmu, cakap, kreatif, mandiri, dan menjadi warga negara yang demokratis serta bertanggung jawab. Dari hasil penelitian Implementasi pendidikan karakter di sekolah dilaksanakan diluar kelas maupun di ruang kelas ketika jam pelajaran berlangsung, hal ini dimaksudkan agar para peserta didik lebih memahami nilai-nilai karakter maupun sikap-sikap yang dibentuk ketika pelaksanaan pendidikan karakter tersebut, dengan begitu siswa akan berperilaku yang baik di lingkungan sekolah maupun di lingkungan masyarakat nantinya. Pelaksanaan pendidikan karakter yang berlangsung diluar kelas Jika dilihat dari hasil wawancara peneliti dengan informan maka pelaksanaan pendidikan karakater yang dapat membentuk sikap dan perilaku sosial peserta didik SMP ALIRSYAD Surakarta dimulai dari proses pembiasaan terhadap peserta didik yang dilakukan oleh pihak sekolah setiap harinya.Kegiatan yang dilakukan setiap hari ini akan berdampak positif terhadap peserta didik yang nantinya membentuk sikapsikap sosial peserta didik itu sendiri seperti bentuk penerapan $5 \mathrm{~S}$ (senyum, sapa, salam, sopan, dan santun), Selain itu bersalaman dengan guru, menuntun sepeda onthel saat memasuki lingkungan di SMP AL-IRSYAD Surakarta dan Parkir sepeda onthel yang tertib. Pelaksanaan pendidikan karakter di SMP AL-IRSYAD Surakarta hanya dilakukan di luar kelas tetapi juga dilaksanakan di dalam kelas. Proses Implementasi pendidikan karakter dalam membentuk sikap dan perilaku sosial peserta didik melalui pembelajaran Bahasa Indonesia dapat dilihat dari beberapa aspek mulai dari perencanaan, pelaksanaan dan evaluasi.

Berdasarkan hasil penelitian, dalam membangun sumber daya manusia yang unggul dalam berprestasi dan memiliki pribadi yang baik, SMP AL-IRSYAD Surakarta menjalin kerja sama dengan semua komponen sekolah (kepala sekolah, guru, staf, siswa, dan orang tua/wali murid) dan secara bersama-sama menyatukan langkah untuk membangun karakter yang baik di lingkungan sekolah. Strategi yang dilakukan SMP AL-IRSYAD Surakarta dalam mengimplementasikan pendidikan karakter melalui kultur 
sekolah. Dan pembelajaran yang digunakan oleh guru Bahasa Indonesia SMP AL-IRSYAD Surakarta menunjukkan bahwa perangkat pembelajaran tersebut sudah dikembangkan dengan mengintegrasikan nilai-nilai yang dikembangkan dalam pendidikan karakter bangsa ke dalam RPP. Sedangkan di dalam silabus tidak di muat secara eksplisit nilai nilai karakter yang harus di miliki siswa. Begitu juga dengan nilai karakter nilai karakter yang dikaitkan dan disesuaikan dengan KD dan materi sejarah. Dari hasil wawancara guru dan siswa menunjukkan bahwa pembelajaran bahasa indonesia sangat berperan dalam pembentukan karakter sikap dan perilaku sosial siswa. Karena dalam materi Bahasa Indonesia terdapat cerita rakyat, dongeng, cerpen, novel, fabel, dll yang dapat di jadikan contoh untuk bersikap dan berperilaku sosial.

Kegiatan rutin merupakan kegiatan yang dilakukan seluruh warga sekolah secara terus-menerus dan konsisten setiap saat. Di SMP AL-IRSYAD Surakarta kegiatan rutin yang dilaksanakan seperti berikut.

a. Budaya $3 \mathrm{~S}$ sekolah memiliki kultur 3S yang tercermin dalam senyum, salam, dan sapa. Budaya 3S dilaksanakan setiap hari senin sampai jumat di waktu pagi sebelum jam masuk sekolah. Budaya 3S dilakukan oleh kepala sekolah, guru, dan karyawan dengan berdiri di depan gerbang sekolah menyambut siswa dengan berjabat tangan.

b. Sholat berjamaah sholat berjamaah ini dilakukan setiap hari ketika sholat dhuha, dhuhur, dan ashar. Kegiatan ini dilakukan oleh siswa dengan guru yang ingin sholat berjamaah. Kegiatan ini dilaksanakan agar dapat menumbuhkan karakter siswa religius dan memiliki tanggung jawab terhadap agamanya.

c. Setiap hari jumat minggu ke-5 di SMP AL-IRSYAD Surakarta memiliki agenda sholat dhuha berjamah, ceramah, dan berbagi nasi keseluruh masyarakat disekitar SMP AL-IRSYAD Surakarta.

d. Upacara rutin sekolah memiliki jadwal upacara setiap hari senin. Hal ini dilakukan untuk menanamkan nilai kedisiplinan dan menumbuhkan sikap nasionalisme siswa. Apabila dalam upacara rutin ada siswa yang datang terlambat dan tidak memakai seragam lengkap, maka akan mendapat pembinaan, yaitu menulis ayat-ayat suci Al-qur'an dan Hadits.

Kurikulum yang diterapkan di sekolah dalam mewujudkan kultur sekolah yang berkarakter meliputi mata pelajaran, berbagai kegiatan/pengalaman belajar, dan proyek sosial. Dalam hal ini, guru secara aktif mengajarkan nilai-nilai, norma-norma, dan kebiasaan karakter yang telah menjadi prioritas sekolah dengan 
mengintegrasikan ke dalam mata pelajaran. Pengembangan nilainilai budaya dan karakter diintegrasikan dalam setiap pokok bahasan setiap mata pelajaran. Nilai-nilai tersebut dicantumkan dalam Silabus dan RPP melalui cara sebagai berikut. Pertama, mengkaji Standar Kompetensi (SK) dan Kompetensi Dasar (KD) pada Standar Isi (SI) untuk menentukan apakah nilai-nilai budaya dan karakter yang tercantum itu sudah tercakup di dalamnya. Kedua, menggunakan tabel yang memperlihatkan keterkaitan antara Standar Kompetensi (SK) dan Kompetensi Dasar (KD) dengan nilai dan indikator untuk menentukan nilai yang akan dikembangkan. Ketiga, mencantumkan nilai-nilai budaya dan karakter dalam tabel itu ke dalam silabus. Keempat, mencantumkan nilai-nilai yang sudah tertera dalam Silabus ke dalam RPP. Kelima, mengembangkan proses pembelajaran peserta didik secara aktif yang memungkinkan, Keenam, peserta didik memiliki kesempatan melakukan internalisasi nilai dan menunjukkannya dalam perilaku yang sesuai.

\section{SIMPULAN}

Dari hasil pemaparan analisis diatas maka dapat disimpulkan bahwa proses pelaksanaan pendidikan karakter dalam membentuk sikap sosial peserta didik di SMP Al-Irsyad Surakarta dilakukan dengan mengintegrasikan nilai-nilai karakter ke dalam pembelajaran Bahasa indonesia dengan begitu nila-nilai karakter bisa tertanamkan kepada peserta didik. Dalam mengintegrasikan pembelajaran tersebut guru bahasa indonesia menyisipkannya kedalam RPP. Nilai-nilai karakter nantinya akan disesuaikan dengan materi yang akan diajarkan di kelas. Selanjutnya guru juga melatih siswa untuk selalu menerapkan karakter-karakter sikap dan perilaku sosial di lingkungan sekolah maupun di lingkungan masyarakat serta menerapkan langsung ketika pembelajaran berlangsung seperti ketika guru memberi tugas kepada siswa dimana siswa harus bersikap ju jur dalam mengerjakan tugasnya yang artinya peserta didik diharapkan tidak mencontek tugas siswa lain. Sesuai dengan kompetensi sikap sosial yang harus dibentuk dalam kurikulum 2013 dimana di dalamnya telah mencangkup seluruh sikap sosial yang berkaitan langsung kompetensi inti dua maka SMP Al-Irsyad Surakarta telah menyesuaikan sikap-sikap yang dibentuk dalam pembelajaran Bahasa indonesia, kompetensi sikap yang dibentuk dalam proses pendidikan karakter di SMP AlIrsyad Surakarta antara lain Jujur, disiplin, tanggung jawab, toleransi, gotong royong, santun, percaya diri. Perilaku sosial Siswa di SMP Al-Irsyad Surakarta juga sudah baik walaupun masih terdapat beberapa siswa yang melanggar aturan yang di terapkan di SMP Al-Irsyad Surakarta. Kendala yang di alami guru Bahasa 
Indonesia pada implementasi pendidikan karakter dalam membentuk sikap dan perilaku sosial peserta didik adalah peraturan pemerintah yang sering berubah-ubah dalam administrasi sebelum mengajar, dan karakter siswa yang berbeda.

Implementasi pendidikan karakter tidak terlepas dari peran semua pihak di sekolah. Seorang kepala sekolah mempunyai posisi strategis dalam menentukan kebijakan pendidikan karakter di sekolah. Guru sebagai pendidik, fungsi utamanya yaitu pelaksana kebijakan pendidikan karakter untuk diimplementasikan kepada siswa. Demikian halnya dengan karyawan juga turut mendukung terciptanya karakter sekolah yang baik. Siswa juga berperan aktif untuk mensosialisasikan serta memberikan contoh kepada siswa yang lain untuk membiasakan diri mengimplementasikan nilai-nilai karakter yang dikembangkan di sekolah.

Pelaksanaan pendidikan karakter terealisasi melalui penanaman nilai-nilai karakter dalam kultur sekolah, yaitu melalui penyediaan fasilitas-fasilitas untuk mendu- kung berbagai aktivitas pada program $\mathrm{se}^{-}$kolah maupun yang dibiasakan dalam kehidupan sehari-hari di sekolah. Program- program sekolah tersebut didesain untuk membentuk karakter siswa melalui aktivi- tasaktivitas di lingkungan sekolah yang di- bentuk sedemikian rupa sehingga siswa baik secara sadar maupun tidak sadar telah membiasakan diri dengan nilai-nilai karak- ter yang direncanakan oleh sekolah.

\section{DAFTAR PUSTAKA}

Agboola, Alex.dkk. (2012). Bring Character Educa- tion into Classroom. European Journal Of Educational Research: 1(2).

Efianingrum, A. (2008). Kultur Sekolah un- tuk Membangun Good School. Diakses dar http://staff.uny.ac.id/sites/default/files/tmp/Kultur\%20Sekolah \%20\&\%20 Good\%20School.pdf

Hasan, S. H., et al. (2010). Pengembangan Pen- didikan Budaya dan Karakter Bangsa. Jakarta: Pusat Kurikulum, Badan Penelitian dan Pengembangan, Kemen- terian Pendidikan Nasional.

Kesuma, Dharma, dkk. (2011). Pendidikan Ka- rakter Kajian Teori dan Praktik di Sekolah. Bandung: PT Remaja Rosda Karya. 
Moerdiyanto. (2012). Fungsi Kultur Sekolah Menengah Atas untuk Mengembang-kan Karakter Siswa menjadi Generasi Indonesia 2045. Diakses dari http://staff.uny.ac.id/sites/default/files/penelitian/

Sudrajat, A. (2011). Mengapa Pendidikan Karakter. Jurnal Pendidikan Karakter. I(2) hlm, 47-58.

Utomo, Cahyo Budi dkk. (2017). Peranan Pembela- jaran Sejarah Dalam Penanaman Nilai Karakter Religius dan Nasionalisme di MAN Temanggung. Jurnal Paramitha . 5(2). 